\title{
ИК-спектроскопия в исследовании процессов УФ-модификации иммобилизованного трипсина
}

\author{
Панкова С.М. ${ }^{1}$, Холявка М.Г. ${ }^{1}$, Артюхов В.Г. ${ }^{1}$, \\ Лукин А.Н. ${ }^{1}$, Вышкворкина Ю.А. ${ }^{2}$ \\ ${ }^{1}$ Воронежский государственный университет, Воронеж \\ ${ }^{2}$ Московский физико-технический институт, Москва
}

Поступила в редакцию 1.05.2019 г.

DOI: https://doi.org/10.17308/sorpchrom.2019.19/788

Исследован механизм воздействия УФ-излучения на трипсин, иммобилизованный на матрице среднемолекулярного (200 кДа) и высокомолекулярного (350 кДа) хитозанов. Установлено, что ферментативная активность молекул иммобилизованного трипсина под воздействием УФ-излучения практически не подвержена изменению. Выдвинуто предположение о фотопротекторном эффекте матрицы хитозана. Выявлено, что при дозе 6040 Дж/м² происходят изменения в структуре белкового комплекса, связаные с варьированием количества неупорядоченных структур и $\beta$-слоев в молекуле фермента, $-\mathrm{COO}^{-}$колебаниями аминокислот, проявляющиеся в снижении активности препарата.

Ключевые слова: УФ-излучение, трипсин, хитозан, адсорбционная иммобилизация, ИКспектроскопия/

\section{IR spectroscopy in the research of UV modification processes for immobilized trypsin}

\author{
Pankova S.M. ${ }^{1}$, Holyavka M.G. ${ }^{1}$, Artyukhov V.G. ${ }^{1}$, \\ Lukin A.N. ${ }^{1}$, Vyshkvorkina Y.A. ${ }^{2}$ \\ ${ }^{I}$ Voronezh State University, Voronezh, Russia \\ ${ }^{2}$ Moscow Institute of Physics and Technology, Moscow, Russia
}

Today the solution of theoretical and practical issues related to understanding the mechanism of UV light action on biosystems of various organization levels, patterns of UV induced changes in the structural and functional characteristics of immobilized enzymes remains relevant. In this regard, the study of the physical and chemical properties of proteases under the influence of UV light must be continued and developed. We have investigated the mechanism of the UV light action on trypsin immobilized on the chitosan matrix, since for immobilized enzymes, the number of possible inactivating pathways is substantially less than in the case of soluble proteins.

Two types of chitosan served as carriers for immobilization: medium molecular weight (200 kDa) and high molecular weight $(350 \mathrm{kDa})$. This polymer has biocompatibility, low toxicity and nonimmunogenicity, which causes widespread use of chitosan in medicine and pharmacology. Immobilization of trypsin samples were adsorption method. Determination of the protein amount and activity of trypsin was performed using a modified Lowry method. Statistical processing of the results was performed using student's t-test at $\mathrm{p}<0.05$.

It was found that the enzymatic activity of immobilized trypsin under the influence of UV light substantially is not subject to change. It is suggested a photoprotective effect of chitosan matrix. For a more detailed study of photoprocesses originating from the adsorbed chitosan matrix with trypsin under the action of UV light were investigated IR-spectra of the immobilized enzyme after exposure to UV-irradiation at doses 
of $151-6040 \mathrm{~J} / \mathrm{m}^{2}$. It was revealed that at a dose of $6040 \mathrm{~J} / \mathrm{m}^{2}$ there are changes in the structure of the protein complex, associated with varying the number of disordered structures and $\beta$-layers in the enzyme molecule, $\mathrm{COO}^{-}$amino acid fluctuations, manifested in a decrease in the activity of the drug. The study of the mechanism of ultraviolet light action on biological systems of different organization levels, including the enzyme, today is one of the central problems of biophysics and physical chemistry biology and reveals mechanisms destructive-modifying, regulatory and therapeutic and prophylactic effect UV-radiation.

Keywords: UV light, trypsin, chitosan, adsorption immobilization, IR-spectroscopy

\section{Введение}

В последнее время значительно возрос интерес к изучению структуры и физико-химических свойств белков и ферментов, иммобилизованных на нерастворимых носителях. Особую значимость приобретают работы по выявлению типов взаимодействий энзимов с различными соединениями на молекулярном уровне, способствующие пониманию механизмов действия полиферментных систем и разработке путей регуляции активности биокатализаторов.

Среди широкого спектра гидролитических ферментов наибольшее практическое значение имеют протеазы. Одной из важных областей применения протеолитических ферментов является медицина. Характерной чертой протеаз является избирательное расщепление денатурированных белков некротических тканей при отсутствии воздействия на живые участки, т.е. при помощи ферментативного лизиса из организма в основном удаляются белки омертвевших тканей. Известно, что для иммобилизованных ферментов число возможных инактивирующих механизмов существенно меньше, чем для растворимых белков [1]. Адсорбционный метод иммобилизации отличается простотой и может быть весомым способом моделирования процессов ассоциации-диссоциации важнейших биоструктур клетки [2-5].

Перспективным сорбентом природного происхождения является хитозан, который представляет собой продукт деацетилирования хитина. Данный полимер обладает биосовместимостью, низкой токсичностью и неиммуногенностью, что обуславливает широкое применение этого катионного биополимера в медицине и фармакологии - от покрытий на раны и ожоги до систем направленной доставки лекарств в микрочастицах $[6,7]$.

Фотохимические реакции ферментов - совокупность реакций, приводящих к различным повреждениям белковых молекул и их возможной инактивации. Основными хромофорами в этих системах являются остатки ароматических аминокислот, главным образом, триптофана, тирозина и фенилаланина. УФизлучение инициирует свободнорадикальные фотопроцессы в белках, которые заканчиваются нарушением структуры и инактивацией фермента [8-10].

Методом монохроматического облучения растворов белка светом различных длин волн было показано, что разрушение одного остатка триптофана и одной дисульфидной связи (соответственно из четырех и шести имеющихся) приводит к инактивации трипсина $[8,9]$.

Существует значительное количество методов, позволяющих исследовать структуру белковых молекул. Высокой информативностью отличаются методы оптической колебательной спектроскопии, в частности ИК-спектроскопия, анализ колебательных линий амид I (1600-1700 $\left.\mathrm{cm}^{-1}\right)$, амид II (1500-1600 см$\left.{ }^{-1}\right)$ и амид III (1200-1300 $\mathrm{cm}^{-1}$ ) дает возможность определять процентное содержание элементов вторичной структуры. ИК-спектроскопия является универсальным методом для анализа межмолекулярных взаимодействий. Поэтому ее часто используют для 
подтверждения комплексообразования, для идентификации органических соединений, содержащих большое количество функциональных групп [11-14].

На сегодняшний день актуальным остается решение ряда теоретических и практических вопросов, связанных с пониманием механизма действия УФ-света на биосистемы различного уровня организации, закономерностей УФ-индуцированных изменений структурно-функциональных характеристик иммобилизованных протеолитических ферментов. В связи с этим изучение физико-химических свойств протеаз под влиянием УФ-света необходимо продолжать и развивать.

Цель работы - изучить процессы фотомодификации иммобилизованного на матрице хитозана трипсина после воздействия УФ-излучения на его образцы.

\section{Эксперимент}

В качестве объекта исследования был выбран трипсин быка фирмы «МР biomedicals», субстратом для гидролиза служил бычий сывороточный альбумин (БСА) фирмы «Sigma-Aldrich», носителями для иммобилизации - два вида хитозана, синтезированных ЗАО «Биопрогресс»: хитозан пищевой кислоторастворимый среднемолекулярный (Mr=200 кДа, степень деацетилирования (СД) 82\%) и хитозан кислоторастворимый высокомолекулярный (Mr=350 кДа, СД=94.85\%).

Иммобилизацию трипсина на хитозане осуществляли адсорбционным методом. 1 г носителя помещали на 1 ч при комнатной температуре в $10 \mathrm{~cm}^{3}$ фосфатного буфера (рН 5.8). Далее к суспензии хитозана добавляли 5 мл раствора трипсина и перемешивали в колбе с помощью электрической мешалки в течение 2 ч при температуре $25^{\circ} \mathrm{C}$. Полученную смесь центрифугировали в течение 5 мин при $1500 \mathrm{~g}$, осадок промывали буфером (рН 5.8) до отсутствия белка в промывных водах. Контроль за содержанием белка осуществляли на спектрофотометре СФ-2000 при 280 нм. Определение количества белка в препаратах и активности трипсина проводили модифицированным методом Лоури $[15,16]$.

УФ-облучение растворов свободного и иммобилизованного трипсина осуществляли при их непрерывном перемешивании магнитной мешалкой в термостатируемой кювете $\left(20 \pm 1^{\circ} \mathrm{C}\right)$ с помощью ртутно-кварцевой лампы типа ДРТ400 через светофильтр УФС-1 с полосой пропускания 240-390 нм в течение 1, 3, 5, 10, 20, 30, 40 мин. Доза облучения составила соответственно 151, 453, 755, 1510, 3020, 4530 и 6040 Дж/м².

Регистрацию ИК-спектров анализируемых образцов осуществляли в Центре коллективного пользования научным оборудованием Воронежского государственного университета с помощью ИК-Фурье спектрометра Bruker Vertex70 (Германия). Спектры снимали с неориентированных порошковых образцов. Статистическую обработку полученных результатов проводили с использованием $t$ критерия Стьюдента при уровне значимости $p<0.05$.

\section{Обсуждение результатов}

При УФ-облучении свободного трипсина в дозе 151 и 453 Дж/м² мы наблюдали тенденцию к увеличению активности фермента, начиная с дозы облучения 1510 Дж/м², происходит незначительное снижение его каталитической способности, которое становится статистически значимым при дозах 3020, 4530, 6040 Дж/м². При этих дозах активность трипсина снижается на 28.3, 31.7, 48.6\% соответственно. 
При УФ-облучении фермента, иммобилизованного на матрице пищевого кислоторастворимого среднемолекулярного хитозана, в дозе 453 Дж/м² выявляется тенденция к увеличению активности препарата, а при дозах 4530 и 6040 Дж/м² незначительное ее снижение. После УФ-облучения трипсина, иммобилизованного на матрице кислоторастворимого высокомолекулярного хитозана, в диапазоне доз 1510-6040 Дж/м ${ }^{2}$ фермент сохраняет свою активность практически на первоначальном уровне (рис. 1).

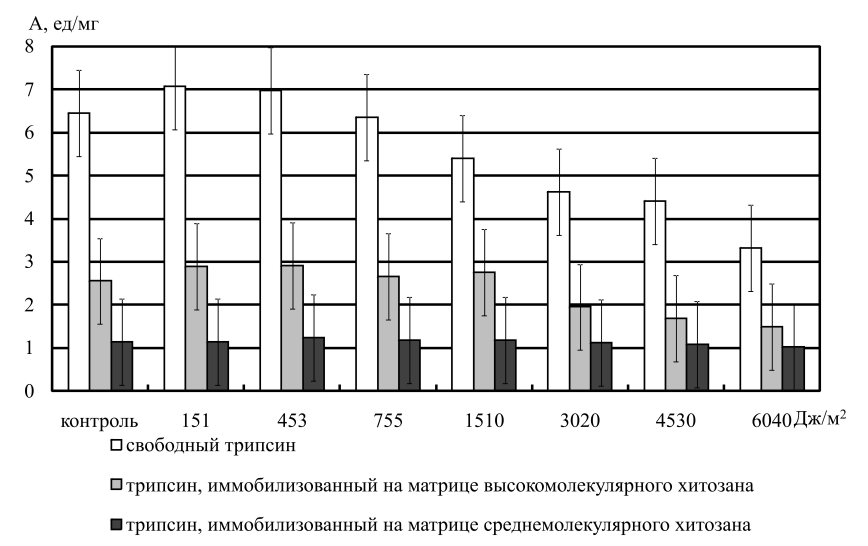

Рис. 1. Влияние УФ-излучения на удельную каталитическую активность (ед/мг белка) трипсина, свободного и иммобилизованного на матрицах высокомолекулярного и среднемолекулярного хитозанов

Приведенные выше данные свидетельствуют о фотопротекторном эффекте матрицы хитозана, который может быть обусловлен следующими причинами: молекула трипсина при взаимодействии с матрицей хитозана образует фоторезистентный комплекс; молекулы хитозана экранируют активные фотопродукты свободнорадикальной природы, предотвращая фотоокисление определенного числа аминокислот фермента при воздействии УФ-облучения.

Для более детального исследования фотопроцессов, происходящих с адсорбированным на матрице хитозана трипсином при действии УФ-света, мы зарегистрировали ИК-спектры иммобилизованного энзима после воздействия УФизлучения в дозах 151-6040 Дж/м².

Анализ ИК-спектров хитозана показывает, что пик $1080 \mathrm{~cm}^{-1}$ соответствует антисимметричному растяжению $\mathrm{C}-\mathrm{O}-\mathrm{C}$ гликозидной связи. Интенсивными полосами поглощения являются $1560 \mathrm{~cm}^{-1}$ (отвечает за вибрацию $-\mathrm{NH}_{2}$ группы), 1640 $\mathrm{cm}^{-1}$ (обусловлена поглощением карбонила). Зарегистрирован пик $2950 \mathrm{~cm}^{-1}$, отражающий -СН-вибрацию, соответствующую пиранозному кольцу. Спектр хитозана характеризуется типичными полосами поглощения $3440 \mathrm{~cm}^{-1}, 2920 \mathrm{~cm}^{-1}$ и $2880 \mathrm{~cm}^{-1}$, которые отвечают за колебания групп -OH, $-\mathrm{CH}_{2}$ и $-\mathrm{CH}_{3}$. Максимум $3370 \mathrm{~cm}^{-1}$ характерен для колебаний анионной группы $-\mathrm{NH}_{2}$. В ИК-спектрах хитозана отсутствовали полосы в области 1670 и $1900 \mathrm{~cm}^{-1}$, указывающие на наличие окисленных карбоксильной и альдегидной групп. Это свидетельствует о том, что функциональные группы хитозана -OH и $-\mathrm{NH}_{2}$, не подвергались окислению, и сохранялась структура биополимера [17-20].

Анализ ИК-спектров трипсина, иммобилизованного на матрице пищевого кислоторастворимого среднемолекулярного хитозана, после воздействия УФ-света в дозах 151-6040 Дж/м² показывает, что наиболее интенсивными в спектрах являются полосы поглощения с максимумами в областях 1542-1586 $\mathrm{cm}^{-1}$ (соответствуют деформационным колебаниям $-\mathrm{NH}_{4}$ и $-\mathrm{C}-\mathrm{NH}_{2}$-групп), 1032-1080 $\mathrm{cm}^{-1}$ (обусловлены 
валентными колебаниями $-\mathrm{CN}$-групп), 2871-2879 $\mathrm{cm}^{-1}$ (проявляются за счет асимметричных и симметричных колебаний $-\mathrm{CH}$ и $-\mathrm{CH}_{2}$-групп), пик $1378 \mathrm{~cm}^{-1}$ (указывает на плоские и неплоские деформационные колебания NH-групп). Присутствуют максимумы поглощения 1550-1646 см-1, которые обусловлены валентными колебаниями аминогрупп белков и доказывают наличие в системе пептидной связи. Фермент вступает в реакцию с хитозаном, используя как амино-, так и гидроксильные группы, поэтому в ИК-спектре комплекса, полученного при взаимодействии энзима с матрицей хитозана, содержатся максимумы поглощения при 1630-1690 см ${ }^{-1}$, отвечающие валентным колебаниям $-\mathrm{N}=\mathrm{C}-$ связи. Необходимо отметить, что, несмотря на наличие некоторых различий в интенсивности полос поглощения, их положение и форма остаются неизменными во всем диапазоне используемых доз.

После УФ-облучения дозой 151 Дж/м² в ИК-спектре трипсина, иммобилизованного на матрице пищевого кислоторастворимого среднемолекулярного хитозана, происходят следующие изменения: появляются пики 3286, 3358, $3412 \mathrm{~cm}^{-1}$, которые исчезают при дальнейшем облучении с повышением дозы. Пик в области поглощения 800-900 $\mathrm{cm}^{-1}$ (обусловлен изменением колебаний пиранозного цикла) становится менее интенсивным. Вышесказанное может объяснять активацию фермента при терапевтических дозах облучения.

При облучении дозами 755 и 3020 Дж/м² в ИК-спектре трипсина, иммобилизованного на матрице среднемолекулярного хитозана, фиксируется пик 1254 и $1245 \mathrm{~cm}^{-1}$ соответственно, эти изменения в полосе амид III связаны с варьированием количества неупорядоченных структур и $\beta$-слоев в молекуле трипсина. После воздействия УФ-света в дозах 755-6040 Дж/м ${ }^{2}$ появляются максимумы поглощения 867-892 $\mathrm{cm}^{-1}$, которые фиксируют изменение степени колебаний пиранозного цикла, при дозах 151-453 Дж/м² данных пиков не выявлено. При повышении дозы облучения препарата происходит незначительный сдвиг пика $1080 \mathrm{~cm}^{-1}$, который соответствует деформационным колебаниям -NH-групп фермента (рис. 2). Вышеприведенные данные могут свидетельствовать об изменениях в структуре энзима, иммобилизованного на матрице кислоторастворимого среднемолекулярного хитозана, приводящих к снижению активности препарата при использовании высоких доз облучения.

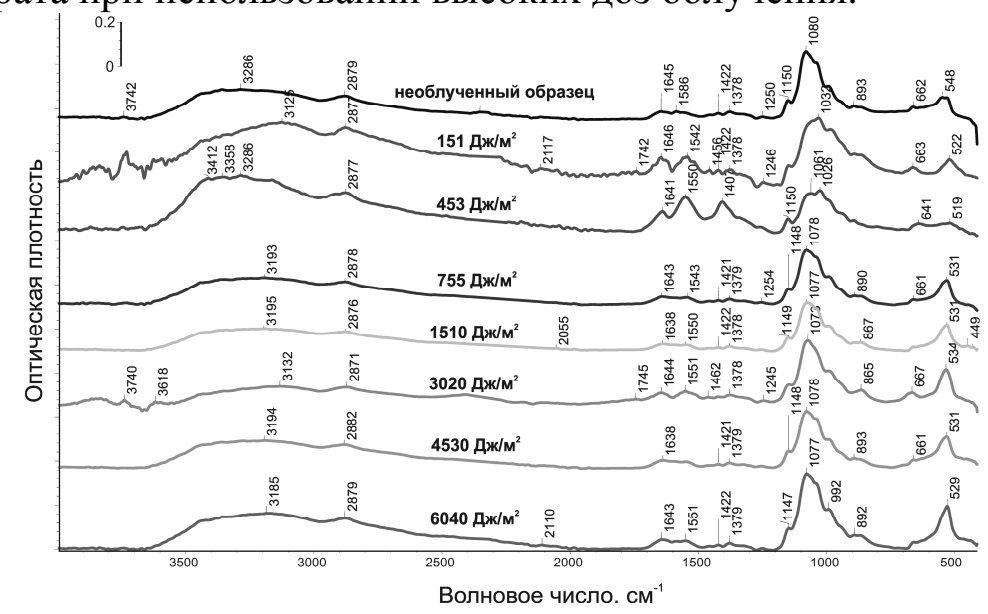

Рис. 2. ИК-спектры трипсина, иммобилизованного на матрице среднемолекулярного хитозана

Анализ ИК-спектров трипсина, иммобилизованного на матрице кислоторастворимого высокомолекулярного хитозана, после воздействия УФ-света в дозах 151-040 Дж/м² показывает, что наиболее интенсивными являются полосы 
поглощения с максимумами в областях 1630-1700 $\mathrm{cm}^{-1}$ (отвечают деформационным колебаниям $\mathrm{NH}_{3}^{+}$, валентным колебаниям $-\mathrm{N}=\mathrm{C}-$ связей), $1500-1600 \mathrm{~cm}^{-1}$ (обусловлены деформационными колебаниями $-\mathrm{N}-\mathrm{H}$ и $\mathrm{C}-\mathrm{NH}_{2}$-группировок), 1200$1300 \mathrm{~cm}^{-1}$ (соответствуют колебанию с участием связи С-O-C), 1000-1100 см (связана с валентными колебаниями $\mathrm{CN}$-связи в первичных аминогруппах). Форма и положение данных пиков сохраняется, что свидетельствует о поддержании стабильности иммобилизованного белкового комплекса. Наблюдается и ряд других менее интенсивных полос поглощения: 2270-2285 см-1 (отвечает колебаниям - $\mathrm{CN}$ и СН-связи), 3120-3130 см-1 (обусловлена наличием $\mathrm{NH}_{2}$-групп аминокислот, валентными колебаниями $\mathrm{NH}_{3}^{+}$). В полосе поглощения 820-870 см${ }^{-1}$ появляются новые пики при дозах облучения 151, 453, 1510, 3020 Дж/м², что обусловлено изменением степени колебания пиранозного цикла. В ИК-спектрах трипсина, иммобилизованного на матрице кислоторастворимого высокомолекулярного хитозана, после воздействия УФ-света в дозах 151-6040 Дж/м² появляются области пиков 955-962 и 3434-3440 $\mathrm{cm}^{-1}$, отвечающие за неплоские деформационные колебания $\mathrm{NH}_{2}-$ групп и асимметричные валентные колебания $\mathrm{NH}_{2}-$ групп соответственно. При облучении дозой 6040 Дж/м² исчезает максимум в области $2100 \mathrm{~cm}^{-1}$, соответствующий $-\mathrm{COO}^{-}$колебаниям аминокислот, что может объяснять снижение каталитической активности препарата (рис. 3).

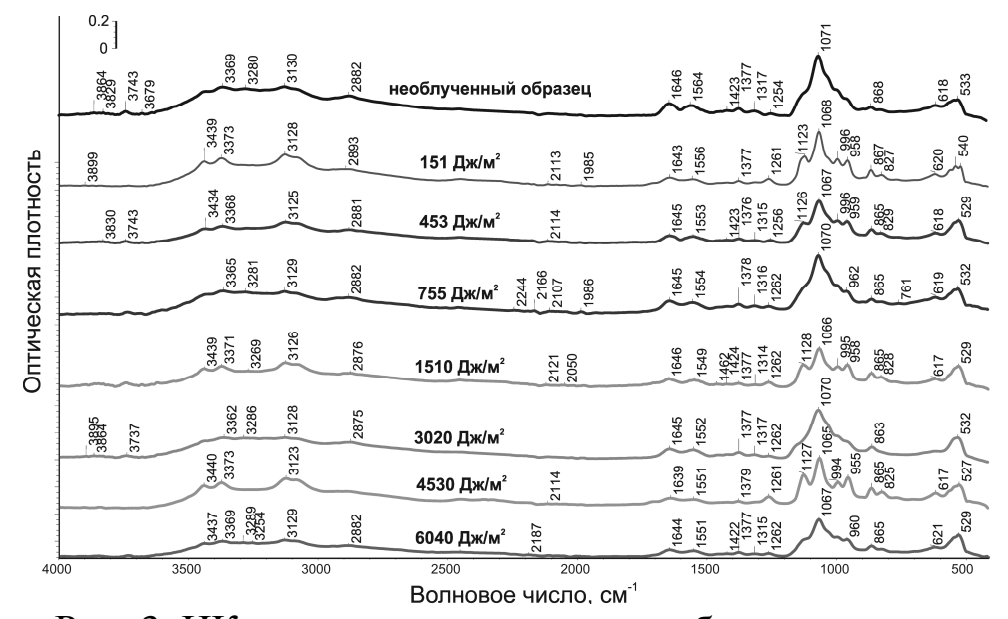

Рис. 3. ИК-спектры трипсина, иммобилизованного на матрице высокомолекулярного хитозана

C повышением дозы облучения происходят сдвиги максимумов полос, связанных с растяжением связи $\mathrm{C}=\mathrm{O}\left(1640-1660 \mathrm{~cm}^{-1}\right.$, полоса амид I) и деформацией связи N-H (1520-1550 см c. $^{-1}$ полоса амид II). При формировании вторичной структуры белка энергии этих пептидных колебаний меняются и приводят к сдвигу полос в ИК-спектре. Пики, отвечающие валентным колебаниям, смещаются в область более низких энергий, поскольку наличие водородной связи облегчает смещение атома азота амидной группы и атома кислорода карбонильной группы в направлении акцептора или донора протона соответственно. Полоса амид II смещается в сторону более высоких энергий, так как водородная связь препятствует изгибанию связи N-H. Фиксируется сдвиг пика от 1254 до $1262 \mathrm{~cm}^{-1}$ с повышением дозы облучения, эти изменения в полосе амид III связаны с варьированием количества неупорядоченных структур и $\beta$-слоев в молекуле фермента.

Как следует из анализа ИК-спектров трипсина, иммобилизованного на матрицах хитозанов кислоторастворимого высокомолекулярного и пищевого кислоторастворимого среднемолекулярного, только при повышении дозы облучения 
образца до 6040 Дж/м² в них происходят изменения, затрагивающие полосы, обусловленные белковым компонентом системы: амид I, амид II и амид III. Исходя из этого, можно констатировать, что матрица хитозана выступает в качестве фотопротектора для иммобилизованного на ней трипсина при терапевтических дозах облучения. При более высоких дозах происходят изменения в структуре белкового комплекса, приводящие к снижению активности препарата при максимальной дозе облучения (6040 Дж/м²).

\section{Заключение}

Таким образом, после иммобилизации на матрице среднемолекулярного (200 кДа) и высокомолекулярного (350 кДа) хитозанов устойчивость трипсина к УФизлучению возрастает, вероятно, за счет образования связей между молекулами фермента и хитозана, повышающих жесткость третичной структуры энзима. При дозе облучения 6040 Дж/м² происходят изменения в структуре белкового комплекса, связанные с варьированием количества неупорядоченных структур и $\beta$-слоев в молекуле трипсина, что приводит к снижению активности данного препарата.

Полученные результаты могут быть полезны при разработке путей комплексного применения УФ-излучения, трипсина и хитозана для восстановления раны или ожога и сокращения сроков заживления кожных покровов, а также при подборе условий стерилизации УФ-светом лекарственных препаратов, содержащих трипсин и хитозан.

\section{Результаты исследований получены на оборудовании ЦКПНО ВГУ}

\section{Список литературы}

1. Холявка М.Г., Артюхов В.Г. Иммобилизованные биологические системы: биофизические аспекты и практическое применение. Воронеж, 2017, $261 \mathrm{c.}$

2. Приворотская Е.А. автореф. дисс. канд. хим. наук, М. 2017. 17 с.

3. Макарова Е.Л. автореф. дисс. канд. биол. наук. Воронеж. 2014. 22 с.

4. Мосолов В.В. Протеолитические ферметы. М. Наука. 1971. 404 с.

5. Жеребцов Н.А., Попова Т.Н., Артюхов В.Г. Биохимия. Воронеж. Изд-во ВГУ. 2002. $696 \mathrm{c}$.

6. Холявка М.Г., Артюхов В.Г., Сазыкина С.М. // Радиачионная биология. Радиоэкология. 2017. Т. 57. № 1. С. 66-70.

7. Костина Н.Ю., Горшкова М.Ю., Изумрудов В.А. // Высокомолекулярные соединения. Серия А. 2011. Т. 53. №10. С. 1767-1775.

8. Владимиров Ю.А., Потапенко А.Я. Физико-химические основы фотобиологических процессов. М. Высшая школа. 1989. 200 с.

9. Артюхов В.Г., Ковалева Т.А., Наквасина М.А., Башарина О.В. и др. Биофизика. М. Академический Проект. 2009. 294 с.
10.Рощупкин Д.И., Артюхов В.Г. Основы фотобиофизики. Воронеж. ВГУ. 1997. 116 с.

11. Бурматова О.С., Сальникова К.Е., Лакина Н.В. // Вестник Тверского государственного технического университета. 2015. №1 (27). C. 51-56.

12.Брандт Н.Н., Манькова А.А., Чикишев А.Ю. // Вестник Московского университета. Серия 3: Физика. Астрономия. 2011. №3. С. 74-77.

13.Яковишин Л.А., Гришковец В.И., Кравчук Ж.Н., Никитина В.Н. // Ученые записки Таврического начионального университета имени В.И. Вернадского. Серия: Биология, химия. 2012. Т. 25. № 1 (64). С. 320-326.

14.Сапон Е.С., Лугин В.Г. // Вестник фармащии. 2017. №1 (75). С. 82-92.

15.Логинова О.О., Холявка М.Г., Артюхов В.Г., Беленова А.С. // Фундаментальные исследования. 2013. №11-3. С. 484-487.

16. Логинова О.О., Холявка М.Г., Артюхов В.Г., Беленова А.С. // Вестник ВГУ. Серия: Химия. Биология. Фармачия. 2013. № 2. С. 116-119. 
17.Andrady A., Torikai A., Kobatake T. // Journal of Applied Polymer Science. 1996. Vol. 62. pp. 1465-1471.

18.Praxedes A.P.P., Silva A.J.C., Silva R.C., Lima R.P.A. et al. // Journal of Colloid and Interface Science. 2012. Vol. 376 (1). pp. 255261.

\section{References}

1. Kholyavka M.G., Artyuhov V.G. Immobilizovannye biologicheskie sistemy: biofizicheskie aspekty i prakticheskoe primenenie, Voronezh, 2017, $261 \mathrm{p}$.

2. Privorotskaya E.A. avtoref. diss. kand. him. nauk, M., 2017, 17 p.

3. Makarova E.L. avtoref. diss. kand. biol. nauk, Voronezh, 2014, $22 \mathrm{p}$.

4. Mosolov V.V. Proteoliticheskie fermety. M., Nauka, 1971, 404 p.

5. ZHerebcov N.A., Popova T.N., Artyuhov V.G., Biohimiya. Voronezh. Izd-vo VGU, 2002, $696 \mathrm{p}$.

6. Kholyavka M.G., Artyuhov V.G., Sazykina S.M., Radiacionnaya biologiya. Radioekologiya, 2017, Vol. 57, No 1, pp. 66-70.

7. Kostina N.YU., Gorshkova M.YU., Izumrudov V.A., Vysokomolekulyarnye soedineniya. Seriya A, 2011, Vol. 53, No 10, pp. $1767-$ 1775.

8. Vladimirov YU.A., Potapenko A.YA., Fiziko-himicheskie osnovy fotobiologicheskih processov. M. Vysshaya shkola, M., Vysshaya shkola, 1989, $200 \mathrm{p}$.

9. Artyuhov V.G., Kovaleva T.A., Nakvasina M.A., Basharina O.V. et al., Biofizika, M., Akademicheskij Proekt, 2009, 294 p.

10.Roshchupkin D.I., Artyuhov V.G. Osnovy fotobiofiziki. Voronezh, VGU, 1997, 116 p.

11.Burmatova O.S., Sal'nikova K.E., Lakina N.V., Vestnik Tverskogo gosudarstvennogo

Панкова Светлана Михайловна - аспирант кафедры биофизики и биотехнологии, Воронежский государственный университет, Воронеж, тел.: +7 (473) 220-85-86

Холявка Марина Геннадьевна - д.б.н., доцент кафедры биофизики и биотехнологии, Воронежский государственный университет, Воронеж, тел.: +7 (473) 220-85-86

Артюхов Валерий Григорьевич - д.б.н., профессор, зав. кафедрой биофизики и биотехнологии, Воронежский государственный уни-
19.Ильина А.В., Варламов В.П. // Прикладная биохимия и микробиология. 2016. Т. 52. № 1. C. 5-20.

20.Тарасевич Б.Н. ИК-спектры основных классов органических соединений.: Справочные материалы. М. МГУ. 2012. 54 с.

tekhnicheskogo universiteta, 2015, No 1 (27), pp. 51-56.

12.Brandt N.N., Man'kova A.A., CHikishev A.Yu., Vestnik Moskovskogo universiteta. Seriya 3: Fizika. Astronomiya, 2011, No 3, pp. 7477.

13.YAkovishin L.A., Grishkovec V.I., Kravchuk ZH.N., Nikitina V.N., Uchenye zapiski Tavricheskogo nacional'nogo universiteta imeni V.I. Vernadskogo. Seriya: Biologiya, himiya, 2012, Vol. 25, No 1 (64), pp. 320-326.

14.Sapon E.S., Lugin V.G., Vestnik farmacii, 2017, №1 (75), S. 82-92.

15.Loginova O.O., Holyavka M.G., Artyuhov V.G., Belenova A.S., Fundamental'nye issledovaniya, 2013, No 11-3, pp. 484-487.

16.Loginova O.O., Holyavka M.G., Artyuhov V.G., Belenova A.S., Vestnik VGU. Seriya: Khimiya. Biologiya. Farmaciya, 2013, No 2, pp. 116-119.

17.Andrady A., Torikai A., Kobatake T., Journal of Applied Polymer Science, 1996, Vol. 62, pp. 1465-1471.

18.Praxedes A.P.P., Silva A.J.C., Silva R.C., Lima R.P.A. et al., Journal of Colloid and Interface Science, 2012, Vol. 376 (1), pp. 255261.

19.Il'ina A.V., Varlamov V.P., Prikladnaya biohimiya i mikrobiologiya, 2016, Vol. 52, No 1, pp. 5-20.

20.Tarasevich B.N. IK-spektry osnovnyh klassov organicheskih soedinenij: Spravochnye materialy. M., MGU, 2012, 54 p.

Pankova Svetlana M. - post-graduate student of the Biophysics and Biotechnology Department, Voronezh State University, Voronezh, E-mail: sazykina.93@mail.ru

Holyavka Marina G. - DSci., associated professor of the Biophysics and Biotechnology Department, Voronezh State University, Voronezh, E-mail: holyavka@ rambler.ru

Artyukhov Valery G. - DSci., Full Professor, Head of the Biophysics and Biotechnology Department, Voronezh State University, Voronezh, 
верситет, Воронеж, Тел.: +7 (473) 220-89-81

Лукин Анатолий Николаевич - к.ф.-м.н., доцент кафедры физики твердого тела и наноструктур, Воронежский государственный университет, Воронеж, тел.: +7 (473) 220-83-63

Вышкворкина Юлия Михайловна - студентка, Московский физико-технический институт, Москва
E-mail: artyukhov@bio.vsu.ru

Lukin Anatoly N. - PhD of Physicomathematical Sciences, docent of the Solid State Physics and Nanostructures Department, Voronezh State University, Voronezh, E-mail alukin@phys.vsu.ru

Vyshkvorkina Yulia M. - student, Moscow Institute of Physics and Technology, Moscow, Email: yulia.vyshkvorkina@ phystech.edu 